\title{
HISTOPATOLOGI INSANG IKAN PATIN SIAM (Pangasius hypophthalmus) YANG TERINFESTASI TREMATODA MONOGENEA
}

\author{
Ida Ayu Nyoman Samirani Utami**\#, Amy Azizah Adiati Ciptojoyo**), dan Ngurah Nyoman Wiadnyana**) \\ * Balai Karantina Ikan, Pengendalian Mutu dan Keamanan Hasil Perikanan Kelas II Palembang \\ *) Pusat Karantina Ikan, Badan Karantina Ikan, Pengendalian Mutu dan Keamanan Hasil Perikanan \\ **) Pusat Riset Perikanan, Badan Riset dan Sumber Daya Manusia Kelautan dan Perikanan \\ (Naskah diterima: 1 Maret 2017; Revisi final: 19 Juni 2017; Disetujui publikasi: 19 Juni 2017)
}

\begin{abstract}
ABSTRAK
Ikan patin siam (Pangasius hypophthalmus) yang terinfestasi parasit trematoda monogenea tidak mudah dikenali gejala klinisnya secara spesifik, mengingat parasit ini menyerang organ insang. Infeksi parasit ini dapat menyebabkan kematian ikan sehingga sangat merugikan budidaya ikan patin siam. Tujuan penelitian adalah memberikan informasi secara histopatologi tentang perubahan jaringan insang ikan patin siam yang terinfestasi parasit trematoda monogenea. Penelitian ini diawali dengan pemeriksaan natif insang patin siam yang terinfestasi parasit trematoda monogenea dan dilanjutkan dengan pemeriksaan histopatologi. Pengambilan sampel ikan patin siam dilakukan sebanyak dua kali pada Mei dan Oktober 2015 di beberapa kolam budidaya. Pengamatan sampel dilakukan secara mikroskopik di Laboratorium Balai Karantina Ikan, Pengendalian Mutu dan Keamanan Hasil Perikanan, Palembang. Hasil penelitian menunjukkan bahwa dari total 150 sampel yang diamati terdapat 35 sampel atau kasus insang ikan yang terinfestasi parasit trematoda monogenea yaitu: masing-masing sebanyak 10 sampel diperoleh pada Mei dan 25 sampel pada Oktober. Pemeriksaan patologi terhadap organ insang yang terinfestasi trematoda monogenea menunjukkan bahwa lamella insang mengalami pembengkakan dan berwarna merah pucat. Parasit trematoda monogenea pada insang atau yang lebih dikenal dengan cacing insang memiliki panjang tubuh berkisar antara 0,7-0,9 mm dengan lebar 0,05-0,10 mm. Pengamatan histopatologi menunjukkan bahwa jaringan insang yang terinfestasi parasit trematoda monogenea ditandai adanya perubahan yang konsisten, yaitu hiperplasia tulang rawan hyalin, proliferasi sel mukus, hiperplasia lamella sekunder, dan fusi lamella sekunder. Perubahan ini dapat mengakibatkan kematian pada ikan akibat kekurangan oksigen dan perubahan osmoregulasi ion dalam tubuh ikan.
\end{abstract}

\section{KATA KUNCl: $\quad$ histopatologi; insang; ikan patin siam (Pangasius hypophthalmus); trematoda monogenea}

\section{ABSTRACT: Histopathology of gills on striped catfish (Pangasius hypophthalmus) infested with trematodes monogenea}

\begin{abstract}
The gills of striped catfish (Pangasius hypophthalmus) infested with parasitic trematodes monogenea are not easy to observe specifically clinical symptoms, the parasite is very harmful to the striped catfish farming. The objective of the study was to provide histopathologic information about changes in gill tissue of infected pangasius fish infested with monogeneous trematoda parasites. This study begun with an examination of native gill of striped catfish and fish infested with parasitic trematodes monogenea and continued with histopathologic examination. Striped catfish samplings were performed twice in May and October 2015 in some aquaculture ponds. Sampel analysis was done microscopically in Laboratorium of Fish Quarantine, Quality Control and Fisheries Product Safety Palembang. The results showed that among of 150 samples there were 35 samples of fish infested with parasitic trematodes monogenea, which of 10 and 25 samples were collected in May and October, respectively. The results on clinical symptoms of infected gills trematodes monogenea showed that gills swelled in lamella gills and pale red. The parasitic trematodes monogenea found in the gills which are well known as the gill worm had a body length ranging from 0.7 to $0.9 \mathrm{~mm}$ with a width of 0.05 to 0.10
\end{abstract}

\footnotetext{
\# Korespondensi: Balai Karantina Ikan, Pengendalian Mutu dan Keamanan Hasil Perikanan Kelas II Palembang. Jl. Akses Bandara Int. I SMB II, Palembang 30152, Indonesia.

Tel.: + (0711) 7302265

E-mail: ngurah_prpt@ indo.net.id
} 
$\mathrm{mm}$. On examination of the gills infested with parasitic trematodes monogenea the histopathological changes were consistent, namely hyalin cartilage hyperplasia, mucous cell proliferation, hyperplasia secondary lamella, and the fusion of the secondary lamella. These changes could be affected on fish mortality due to lack of oxygen and ion osmoregulation changes in the body of the fish.

\section{KEYWORDS: Hispatology; gills; striped catfish (Pangasius hypophthalmus); trematodes monogenea}

\section{PENDAHULUAN}

Ikan patin siam (P. hypophthalmus) merupakan komoditas ikan air tawar unggulan, khususnya Sumatera Selatan dan telah mangalami perkembangan budidaya yang cukup pesat. Penerapan intensifikasi budidaya dengan peningkatan padat tebar sering dilakukan untuk memenuhi permintaan pasar. Namun, intensifikasi budidaya dapat menimbulkan berbagai dampak negatif antara lain timbulnya penyakit pada ikan. Penyakit merupakan masalah serius yang harus dihadapi oleh para pembudidaya ikan, karena sangat berpotensi menimbulkan kerugian yang tinggi. Kerugian tersebut dapat berupa kematian ikan dan penurunan kualitas ikan sehingga secara ekonomis akan berakibat pada penurunan harga (Khairuman \& Sudenda, 2009). Munculnya penyakit pada ikan umumnya merupakan hasil interaksi yang tidak seimbang antara tiga komponen dalam ekosistem perairan yaitu inang (ikan) yang lemah, patogen yang ganas, serta kualitas lingkungan yang memburuk (Snieszko, 1973; Saputra et al., 2013). Kondisi yang tidak seimbang pada ketiga komponen tersebut menyebabkan upaya pengendalian penyakit sangat sulit dicapai, karena secara faktual ikan selalu hidup bersama patogen yang setiap saat berpotensi menyebabkan penyakit.

Salah satu penyakit yang menyerang ikan budidaya dan berpotensi menimbulkan kerugian cukup besar adalah serangan parasit (Tobing, 2000; Afrianto \& Liviawaty, 2003; Bandilla et al., 2006). Keberadaan trematoda monogenea pada ikan biasanya sebagai parasit pada insang atau kulit yang menyebabkan kematian massal karena ikan kehabisan darah karena parasit ini mengonsumsi darah dan mengganggu sirkulasi darah melalui insang dan kasus seperti ini sering terjadi pada ikan lele (Clarias sp.) (Hadiroseyani et al., 2006).

Keberadaan trematoda monogenea pada insang ikan sangat sulit diamati secara kasat mata, karena ukuran parasit ini sangat kecil. Untuk itu, pemeriksaan dilakukan dengan mengambil sampel insang ikan yang diduga terinfeksi trematoda monogenea dan diamati dengan mikroskop.

Jenis parasit yang dapat menyerang pada ikan adalah golongan protozoa, cacing, dan krustasea (Kabata, 1985). Cacing yang sering menyerang insang patin siam sangat jarang menimbulkan gejala klinis secara makroskopis (Bamidele, 2007) tetapi menunjukkan perubahan histo patologi yang sangat konsisten. Parasit golongan cacing terbagi menjadi Plathyhelminthes, Nematoda, dan Acanthocepala. Infestasi cacing yang sering ditemukan pada insang ikan patin siam adalah berasal dari kelas Trematoda monogenea dan Ordo Plathyhelminthes (Hoffman, 1999).

Histopatologi merupakan suatu teknik atau ilmu yang mempelajari perubahan abnormal dari sel atau jaringan yang digunakan untuk mendiagnosa penyakit. Pemeriksaan secara histopatologi merupakan pendukung dari suatu diagnosa dan dapat menjadi pemeriksaan diagnosa utama dari suatu penyakit dengan ditemukannya perubahan sel atau jaringan yang spesifik pada penyakit tertentu. Pada saat yang bersamaan, pemeriksaan histopatologi merupakan pemeriksaan lanjutan dari penyakit parasit pada insang ikan, karena perubahan yang terjadi sering diakibatkan karena perubahan lingkungan (air pemeliharaan ikan) yang terjadi secara ekstrem (Hossain et al., 2007). Untuk itu, perlu dilakukan pemeriksaan histopatologi lebih lanjut untuk mengetahui gambaran perubahan sel dan jaringan dari insang yang terinfestasi tremato da monogenea.

Penelitian ini bertujuan untuk memberikan informasi secara histopatologi tentang perubahan jaringan insang ikan patin siam yang terinfestasi parasit trematoda monogenea.

\section{BAHAN DAN METODE}

\section{Pengamatan Parasit Secara Natif}

Pengumpulan sampel ikan patin siam, dengan ukuran total antara 28-32 cm dan bobot 200-300 g, dilakukan pada Mei dan Oktober 2015 di beberapa kolam budidaya di Sumatera Selatan. Sebanyak 75 sampel insang diambil pada setiap pengamatan dan diperiksa di Laboratorium Parasitologi dan Histologi Balai Karantina Ikan, Pengendalian Mutu dan Keamanan Hasil Perikanan Kelas II Palembang. Dari jumlah total 150 sampel yang diamati teridentifikasi 35 sampel insang yang teinfestasi parasit trematoda monogenea (cacing insang). Jumlah cacing insang yang ditemukan pada setiap insang ikan patin siam berkisar antara 2-3 ekor, jumlah seluruh cacing yang diperoleh sebanyak 89 ekor dan diukur panjang, serta lebar 
badannya. Selanjutnya untuk pengamatan histopatologi, ikan patin siam dianastesi dan dinekropsi, kemudian diamati perubahan pada filamen/ lamella insang. Sebanyak 4-5 filamen insang diambil untuk diletakkan di atas gelas objek yang sudah ditetesi cairan $\mathrm{NaCl}$ fisiologis dan ditutup dengan gelas penutup. Preparat diamati dengan mikroskop cahaya dan direkam menggunakan kamera perekam. Setelah diperoleh parasit yang mengarah pada trematoda monogenea, insang dibilas dengan cairan $\mathrm{NaCl}$ fisiologis secara perlahan dan dilanjutkan dengan proses pembuatan preparat histologis. Dari sampel insang yang terinfestasi cacing trematoda monogenea, satu preparat sampel cacing yang paling sempurna diamati morfologinya di bawah mikroskop dengan pembesaran 400x.

\section{Preparasi dan Pengamatan Preparat Histologis}

Sampel ikan yang teridentifikasi terinfestasi parasit pada insang di laboratorium Parasitologi, selanjutnya difiksasi menggunakan phospatebuffered formalin (NBF) 10\%selama 24-48 jam (Raškoviæ et al., 2011). Setelah dilakukan fiksasi, dilanjutkan dengan proses dehydrasiclearing-embedding dalam larutan alkohol dengan konsentrasi bertingkat dan larutan xilol, serta ditanam dalam paraffin. Semua proses tersebut dilakukan dengan alat tissue processor. Blok-blok yang terbentuk dari proses embbeding kemudian dipotong menggunakan mikrotom dengan ketebalan sayatan 3-5 $\mu \mathrm{m}$. Pita hasil pemotongan diregangkan dengan cara dimasukkan ke dalam waterbath bersuhu stabil $40^{\circ} \mathrm{C}$. Gelas objek digunakan untuk mengambil pita dalam waterbath dan dikering-anginkan selama satu jam. Kemudian, gelas objek disusun dalam staining box dan dilakukan pewarnaan haematoxylin-eosin (HE) dan pada akhir pewarnaan dilakukan covering slide. Preparat diamati dengan mikroskop cahaya dan didokumentasikan menggunakan kamera perekam. Preparat jaringan yang sudah ditutup dengan cover glass diamati di bawah mikroskop dengan pembesaran 400x untuk dianalisis. Analisis jaringan dilakukan secara deskriptif dengan melihat perubahan jaringan yang diakibatkan oleh infestasi parasit trematoda monogenea (Wakita et al., 2007).

\section{HASIL DAN BAHASAN}

Dari total 150 sampel insang patin siam (P. hypophthalmus) yang diamati secara natif dan hispatologi, diperoleh 35 sampel yang terinfestasi parasit trematoda monogenea, yaitu 10 sampel $(13 \%)$ tercatat pada Mei, sedangkan 25 sampel (33\%) ditemukan pada Oktober 2015. Hasil ini menunjukkan bahwa sampel atau disebut kasus infestasi parasit pada insang ikan patin siam lebih banyak terjadi pada
Oktober dibandingkan dengan Mei. Hal tersebut kemungkinan dipengaruhi oleh perubahan kondisi lingkungan. Kondisi lingkungan yang tidak baik dapat memengaruhi tingginya virulensi/tingkat serangan penyakit pada ikan (Snieszko, 1973; Saputra et al., 2013). Pada periode Oktober, umumnya di wilayah Sumatera Selatan sudah memasuki musim penghujan. Pada periode ini limpahan air yang masuk ke kolamkolam budidaya ikan dapat mengandung berbagai bahan organik dan polutan lainnya yang dapat memicu kemunculan berbagai parasit, termasuk parasit trematoda monogenea yang dapat menyerang ikanikan yang dibudidayakan.

Pengamatan makroskopis menunjukkan lamella insang ikan patin siam yang terinfestasi parasit trematoda monogenea terlihat menebal/ pembengkakan dan berwarna lebih pucat (Gambar 1A) dibandingkan dengan lamella insang ikan patin siam yang tidak terinfestasi parasit yang tampak berwarna cerah cemerlang (tidak kusam dan berlendir) dan tidak terjadi penebalan lamella (Gambar 1B). Parasit trematoda monogenea merupakan parasit golongan cacing yang sangat mudah dikenali pada saat pengamatan preparat natif insang ikan patin siam, karena ukuran parasit ini relatif besar dengan panjang dan lebar masing-masing berkisar antara 0,7-0,9 mm dan 0,05-0,10 mm (Gambar 1C). Parasit trematoda monogenea merupakan parasit pada kelas monogenea dengan ukuran terbesar dan memiliki panjang mencapai 0,30-1,00 mm (Kabata, 1985).

Infestasi parasit trematoda monogenea menempel kuat di antara lamella sekunder bahkan sampai menembus tulang rawan hialin. Terkadang pada pemeriksaan preparat natif, parasit hanya tampak menempel pada permukaan lamella sekunder. Parasit ini menempel pada permukaan lamella insang dengan menggunakan opistaptor yang terdiri atas 14 hooks, dua di antaranya berada di dekat anchor (Gambar 1C dan 2A) sebanding dengan yang diperlihatkan pada Gambar 2B dan 2C (Susanto, 2008). Anchor merupakan alat penghisap sari makanan yang dibawa oleh darah saat mengikat oksigen di lamella insang (Kabata, 1985).

Dari hasil pengamatan preparat histologi (Gambar 2A), cacing pada insang ikan patin dapat diidentifikasi sebagai Klas Trematoda monogenea. Pada Gambar 2A, tampak bahwa karakteristik dari parasit ini terlihat pipih dan seperti daun, tidak memiliki bintik mata, ujung kepala berbentuk $\mathrm{V}$, dan seperti kulit kerang, organ menempel (opisthohaptor) memiliki jangkar-jangkar. Potongan parasit ini terdapat diperoleh di antara lamella insang dan beberapa bagian lamella insang dan menyebabkan lamella insang menyatu (fusi lamella sekunder) berbentuk seperti tongkat pemukul (Gambar 4A). Bagian vitellarium, 

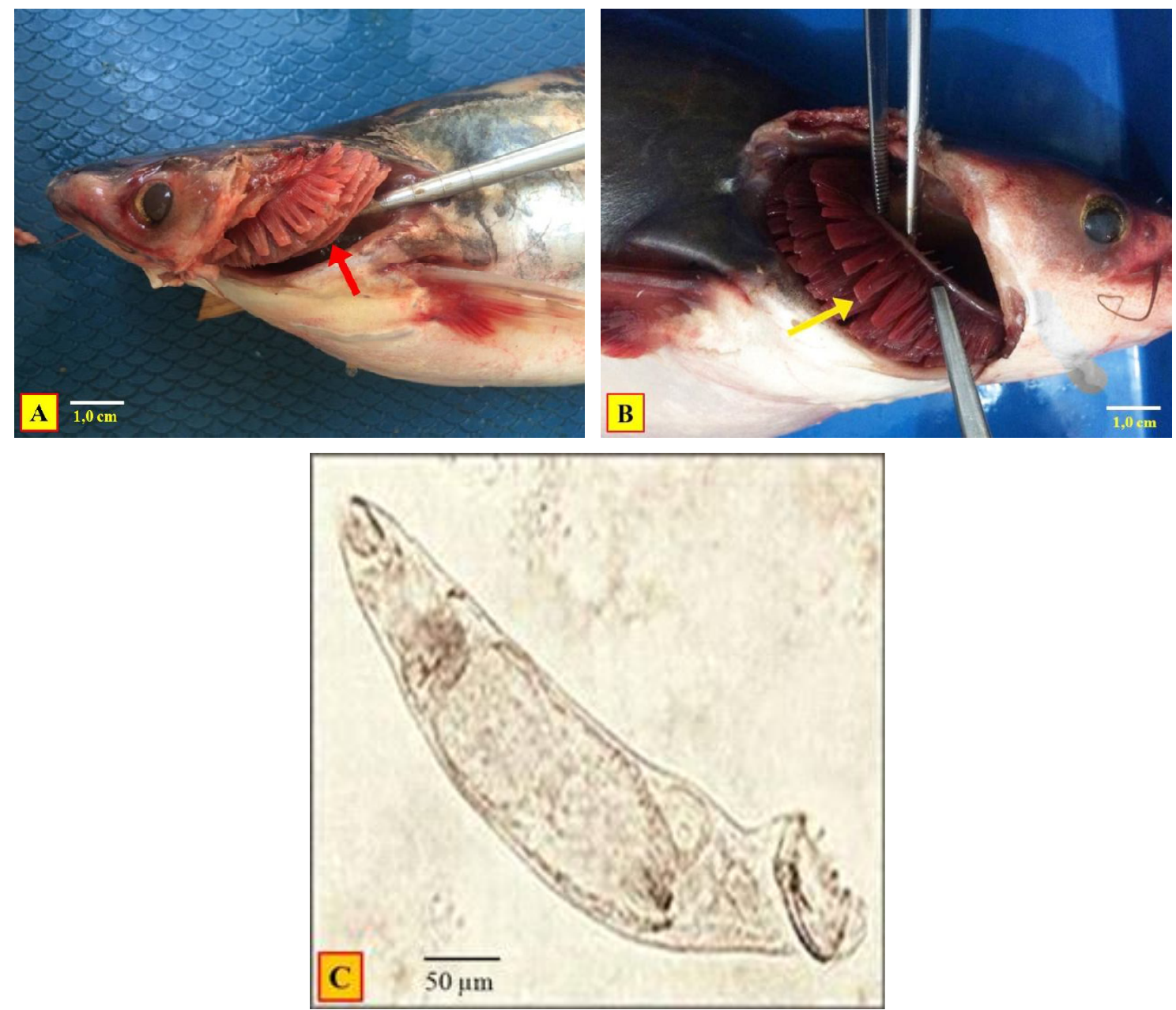

Gambar 1. Perubahan patologi insang ikan patin siam (P. hypophthalmus) yang terinfestasi parasit trematoda monogenea terlihat menebal dan berwarna lebih pucat $(A)$ dan yang tidak terinfestasi parasit trematoda monogenea (B) serta contoh parasit yang memiliki ukuran relatif besar (C).

Figure 1. Pathological change of gill in striped catfish (P. hypophthalmus) which is infested with parasitic trematodes monogenea show thickened and paler (A) and gill was not infested with parasitic trematodes monogenea (B) as well as an example of parasite which has a relatively largesize (C).

saluran pencernaan, eritrosit, jangkar, dan cakram bagian belakang dari parasit trematoda monogenea dapat diamati pada Gambar 2A. Selain itu, dapat juga dilihat parasit trematoda monogenea yang menempel pada insang dengan menggunakan jangkar dan cakram pelekat (Gambar 3) seperti yang dilaporkan sebelumnya oleh Grabda (1991). Lebih jauh dikemukan bahwa parasit trematoda monogenea yang baru menetas akan bersifat parasit bila telah menempel pada insang inang dan menghisap darah inang. Bentuk tubuh monogenea pipih, bagian punggung dan perut (kadang silindris), bulat telur, oval atau menyerupai lempengan melingkar, bagian perut ramping, cekung dan cembung pada bagian punggung. Tipe karakter monogenea adalah memiliki dua atau empat bintik mata anterior, tetapi ada juga yang tidak memiliki bintik mata dan kait-kait belakang sangat jelas.

Perkembangan parasit trematoda monogenea sangat cepat di perairan. Telur yang menetas di perairan akan berenang menggunakan cilia yang disebut oncomirasidium untuk mencari insang definitif yang sesuai dan berkembang infektif pada ikan tersebut (Rohde, 2005). Perkembangan parasit mencapai dewasa terjadi di insang, tepatnya di lamella primer insang (Grabda, 1991). Oncomirasidium masuk ke dalam sel epitel lamella primer dengan memakan sel epitel lamella primer dan tulang rawan hyalin yang ada pada lamella primer dan membentuk kista di dalamnya.

Pengamatan histologi memperlihatkan adanya perubahan hyperplasia selepite lamella sekunder (Gambar 

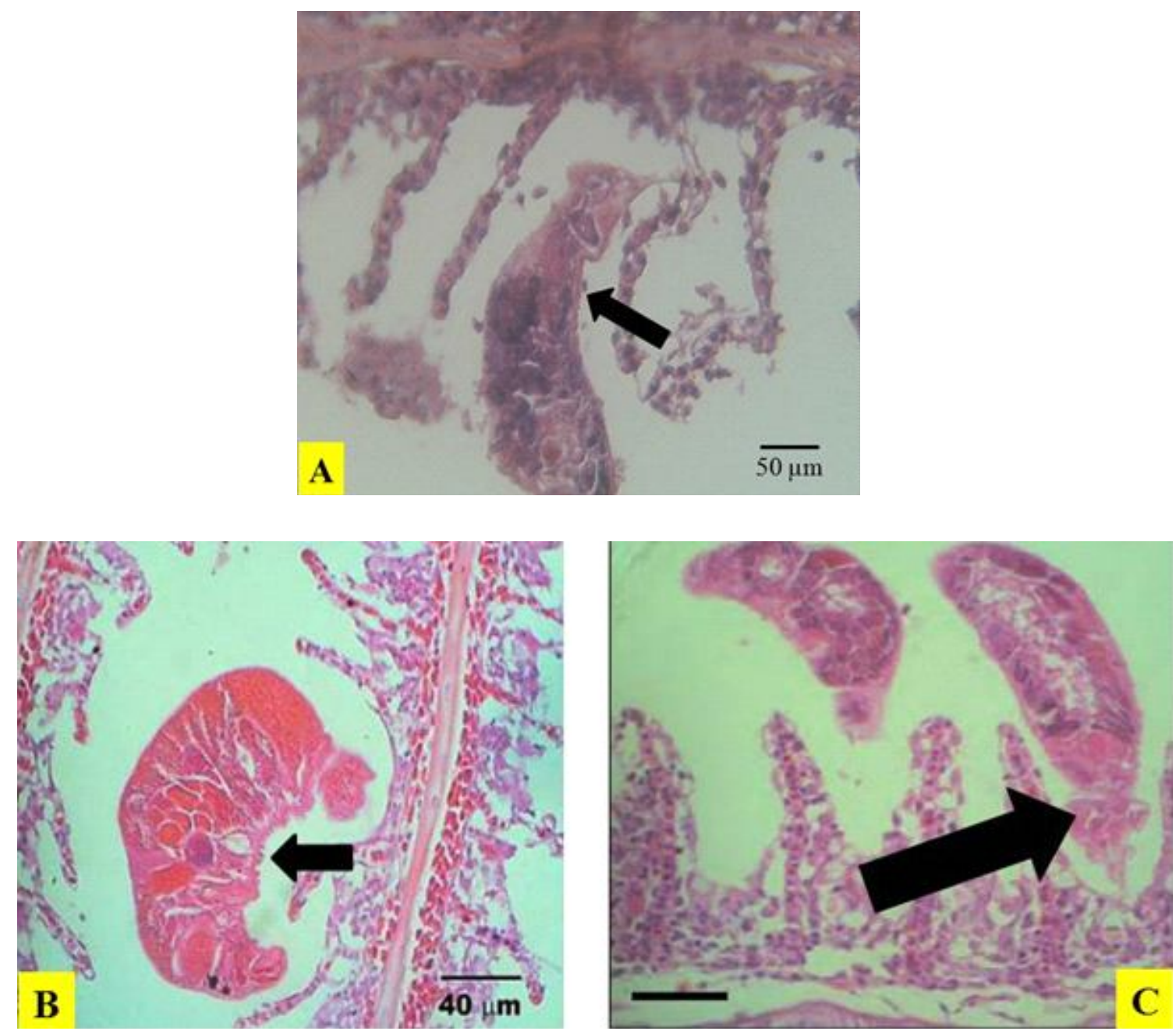

Gambar 2. Insang ikan patin siam (P. hypophthalmus) yang terinfestasi parasit trematoda monogenea (A) dengan pewarnaan $\mathrm{HE}$, 400x sesuai dengan yang dilaporkan oleh Susanto (2008) (B dan C).

Figure 2. $\quad$ Fish gills striped catfish (P. hypophthalmus) infested with parasitic trematodes monogenea (A) with HE staining, 400x in accordance with that reported by Susanto (2008) (B and C).

3). Hal ini terlihat adanya keberadaan kista parasit pada lamella primer yang mengakibatkan terjadinya hiperplasia tulang rawan hyalin dan hiperplasia sel epitel lamella (Rohde, 2005). Selanjutnya dikatakan bahwa hiperplasia tulang rawan hyalin terbentuk karena stimulasi dari parasit trematoda monogenea yang berkembang dari oncomyrasidium menjadi cacing muda. Hiperplasia lamella insang merupakan salah satu pertahanan tubuh terhadap benda asing. Perkembangan parasit pada lamella insang menjadi dewasa dengan memakan sel epitel dan tulang rawan hyalin.

Secara histopatologi, Camargo \& Martinez (2007) mengemukakan bahwa proses pertahanan insang dari perlekatan parasit yang menggunakan anchor dapat mengakibatkan pendarahan. Reaksi pertahanan pada lamella menstimulasi pertumbuhan selepite lamella insang yang sangat cepat (hiperplasia) dan peningkatan dari sekresi mukus oleh sel-sel mukus (Gambar 3). Hiperplasia lamella tidak hanya disebabkan oleh pertumbuhan sel epitel, tapi bisa juga bersinergi dengan proliferasi sel mukus dan fusi lamella sekunder (lamella insang menyatu).

Proliferasi sel mukus yang distimulasi untuk melindungi bagian tubuh yang termakan oleh parasit dengan menghasilkan banyak lendir pada permukaan insang dapat menyebabkan kematian sel (nekrosa) epitel lamella (Hossain et al., 2007). Penambahan jumlah sel menyebabkan lapisan epitel lamella sekunder yang hanya satu lapis menjadi tampak berlapis-lapis (Gambar 4A). Nekrosa yang diakibatkan hipersekresi mukosa menimbulkan perforasi dari pembuluh darah, sehingga oksigen dan nutrisi tidak 


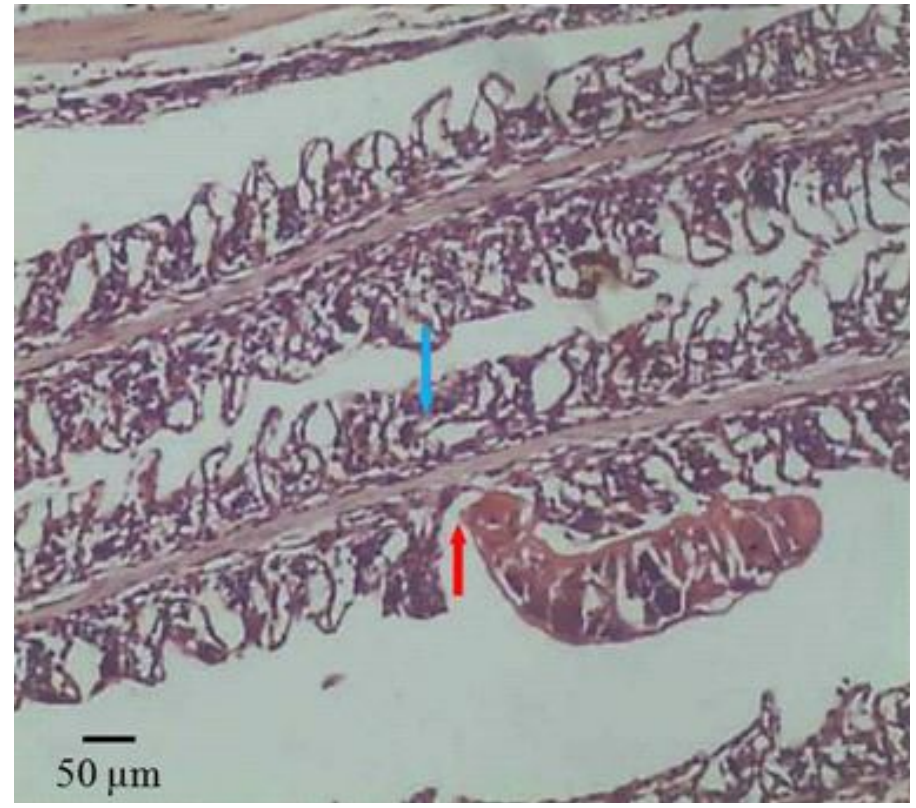

Gambar 3. Anchor parasit trematoda monogenea (panah merah) yang melekat pada lamella insang dan menyebabkan hyperplasia sel epitel lamella (panah biru) (pewarnaan $\mathrm{HE}, 400 \mathrm{x}$ ).

Figure 3. The head (anchor) parasitic trematodes monogenea (red arrow) is attached to the lamella gills and cause epithelial cell hyperplasia lamella (blue arrow) (HE staining, 400x).

sampai di lokasi hiperplasia sel epitel tersebut, dalam keadaan yang lama akan menyebabkan kematian jaringan (Gambar 3). Menurut Roberts (2001), peningkatan sekresi sel mukus secara nyata mengurangi proses pernafasan pada ikan karena proses osmosis oksigen tidak terjadi pada daerah yang tertutup sekresi mukus dan sel epitel yang sudah nekrosa. Selanjutnya dijelaskan bahwa proliferasi merupakan kondisi di mana sel epitel lamella sekunder tumbuh secara berlebihan akibat dari gigitan parasit trematoda monogenea tersebut sehingga menyebabkan produksi lendir meningkat dan pada akhirnya menghasilkan sel epitel lamella sekunder menjadi berlebih. Proliferasi epitel lamella sekunder (epitel lamella sekunder tumbuh secara berlebihan), diduga kondisi tersebut disebabkan oleh serangan parasit. Proliferasi sel-sel lamella yang terjadi merupakan respons dari infeksi yang lama maupun cepat. Bentuk tidak normal dari sel-sel lamella ini juga dapat terjadi akibat reaksi terhadap gangguan kimia misalnya perubahan $\mathrm{pH}$ yang menjadi lebih asam di kolam yang perairannya tidak bersirkulasi dengan baik sehingga terjadi penumpukan gas karbondioksida $\left(\mathrm{CO}_{2}\right)$. Selain bersumber dari hasil metabolisme ikan cemaran pada air juga dapat berasal dari lingkungan perairan seperti sampah atau buangan industri. Selanjutnya dikemukakan Price \& Wilson (2006), proliferasi merupakan suatu keadaan di mana terjadi peningkatan atau kenaikan jumlah sel yang nyata dalam jaringan. Proliferasi sel-sel lamella yang terjadi merupakan respons dari infeksi yang lama maupun cepat. Proliferasi sel epitel lamella sekunder yang terjadi pada insang merupakan respons dari adanya parasit atau bahan asing seperti bahan-bahan kimia organik.

Insang ikan yang teinfestasi parasit trematoda monogenea mengakibatkan terjadinya fusi lamella insang (lamella insang menyatu) dari lamella sekunder (Gambar 4A). Akibat dari adanya fusi ini, lamella insang tidak dapat berfungsi dengan baik, karena lakuna yang berisi sel darah merah tertutup oleh sel epitel lamella sekunder. Pemulihan lamella insang akan ditandai dengan luka tertutup oleh banyaknya sel interlamella setelah terjadi nekrosis pada sel epitel dan pecah oleh kerusakan secara fisik, kimiawi, dan biologi (Robert, 2001). Namun, bila kerusakan terjadi semakin parah maka insang berada pada kondisi dengan ruang antara lamella sekunder dengan sel interlamella yang berdekatan seperti terlihat pada Gambar 4D (Wakita et al., 2007). Lamella insang akan terlihat menyatu seperti tongkat pemukul (Gambar 4A), seperti juga diperlihatkan pada Gambar 4C (Wakita et al., 2007). Kerusakan berupa lamella insang menyatu seperti tongkat pemukul dapat mengakibatkan efisiensi 
pernafasan eksternal menjadi sangat buruk karena lamella sekunder telah tertutup sempurna oleh selsel interlamella (ikan berada pada posisi kesulitan bernafas karena kekurangan oksigen).

Seperti yang dikemukakan oleh Robert (2001), hiperplasia terjadi pada tingkat iritasi yang lebih rendah dan biasanya disertai peningkatan jumlah selsel mukus pada dasar lamella dan mengakibatkan fusi lamella insang (lamella insang menyatu) dari lamella.
Ruang interlamella yang merupakan saluran air dan ruang produksi mukus dapat tersumbat akibat hiperplasia sel epitel yang berasal dari filamen primer. Pada akhirnya, seluruh ruang interlamella diisi oleh sel-sel yang baru. Hiperplasia mengakibatkan penebalan jaringan epitel diujung filamen yang memperlihatkan bentuk seperti pemukul bisbol (clubbingdistal) atau penebalan jaringan epitelium yang terletak di dekat dasar lamella (basal hiperplasia) (Gambar 4A dan 4C).
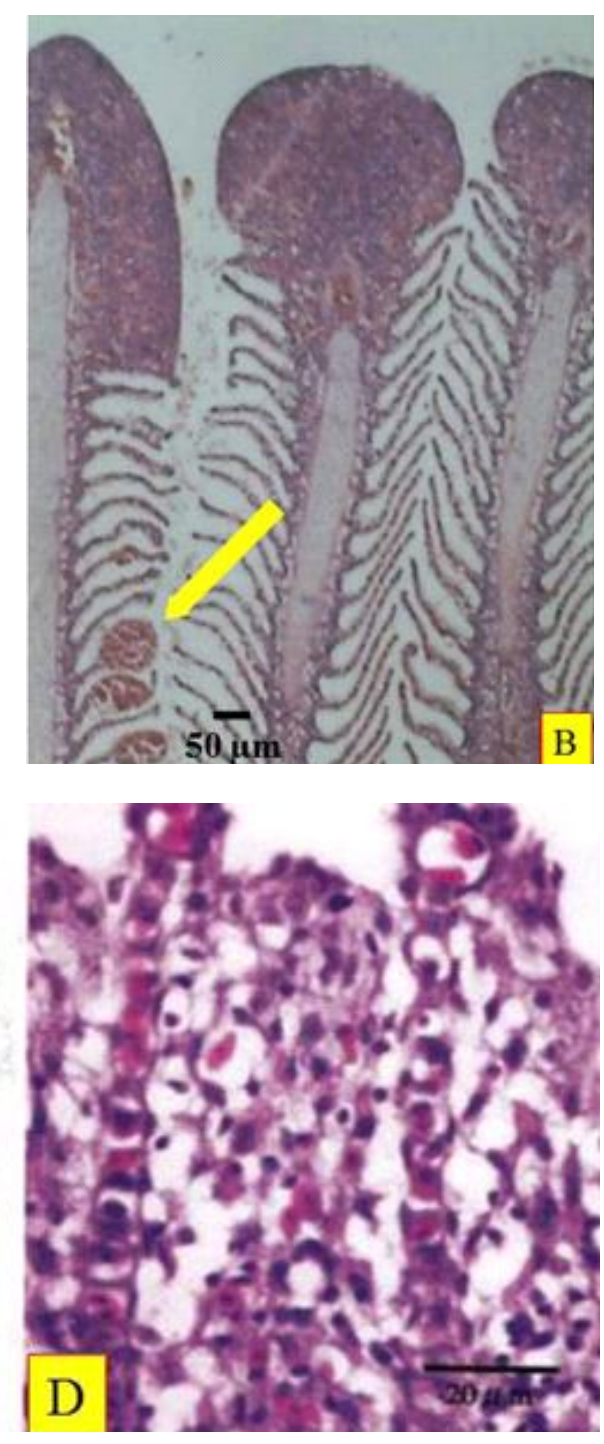

Gambar 4. Mikrofotografi lamella sekunder insang patin siam (P. hypophthalmus), A) fusi lamella sekunder (lamella insang menyatu) karena hiperplasia sel epitel lamella sekunder (panah merah); proliferasi sel mukus (panah biru); B) telangiektasis yang diakibatkan karena pecahnya lakuna akibat dari ruptur sel pilar sehingga terjadi penumpukan sel darah merah pada lamella sekunder (panah kuning) (pewarnaan HE, 400x); C dan D menggambarkan lamella insang menyatu (Wakita et al., 2007).

Figure 4. A microphotography on secondary lamella gills of striped catfish (P. hypophthalmus), A) fusion of secondary lamella (lamella gill fused) for cell hyperplasia secondary lamella epithelium (red arrow); mucous cell proliferation (blue arrow); and B) telangiectasia is caused by the outbreak of the lacuna resulting from pillar cells rupture resulting in accumulation of red blood cells in the secondary lamella (yellow arrows) (HE staining, 400x); C and D illustrate the fusion of the secondary lamella (Wakita et al., 2007). 
Tertutupnya lakuna oleh sel epitel lamella sekunder dapat meningkatkan tekanan yang ada pada lakuna dan mengakibatkan ruptur (patah) dari sel pilar yang berfungsi menjaga kestabilan dari lamella sekunder. Patahnya sel pilar mengakibatkan penumpukan sel darah merah di ujung lamella yang disebut dengan telangiektasis (Gambar 4B). Telangiektasis dapat diakibatkan oleh proses normal tubuh di mana penyerapan oksigen rendah sedangkan kebutuhan oksigen untuk metabolisme sangat tinggi sehingga ikan melakukan homeostasis dengan mempercepat peredaran darah yang mengakibatkan patahnya sel pilar dan memperluas area lakuna di ujung lamella sekunder (Roberts, 2001; Sayed et al., 2012).

\section{KESIMPULAN}

Hasil pengamatan mendapatkan 35 sampel insang atau kasus ikan patin siam terinfestasi parasit trematoda monogenea, yaitu 10 sampel (13\%) dan 25 sampel (33\% masing-masing pada Mei dan Oktober 2015. Insang patin siam (P. hypophthalmus) yang terinfestasi parasit trematoda monogenea terlihat berwarna merah pucat dan mengalami pembengkakan pada lamella. Parasit trematoda monogenea berukuran panjang dan lebar masing-masing antara 0,7-0,9 mm dan 0,05-0,10 mm. Pengamatan histopatologi insang menggambarkan adanya konsistensi perubahan yaitu hiperplasia tulang rawan hyalin, proliferasi sel mukus, hiperplasia lamella sekunder, dan fusi lamella sekunder. Fusi lamella sekunder dapat mengakibatkan terjadinya telangiektasis dan mengakibatkan kematian ikan karena kekurangan oksigen dan perubahan osmoregulasi ion tubuh ikan.

\section{UCAPAN TERIMA KASIH}

Kegiatan penelitian ini dilakukan atas biaya dari alokasi anggaran kegiatan pada 2015 di Balai Karantina Ikan, Pengendalian Mutu dan Keamanan Hasil Perikanan Kelas II Palembang. Ucapan terima kasih disampaikan kepada Kepala Balai dan juga rekan-rekan yang telah membantu kegiatan di lapangan maupun di laboratorium.

\section{DAFTAR ACUAN}

Afrianto, E. \& Liviawaty, E. (2003). Pengendalian hama dan penyakit ikan. Yogyakarta: Kanisius, $89 \mathrm{hlm}$.

Bandilla, M., Valtonen, E.T., Suomalainen, L.R., Aphalo, P.J., \& Hakalahti, T. (2006). A link between ectoparasite infection and susceptibility to bacterial disease in rainbow trout. International Journal for Parasitology, 36, 987-991.
Bamidele, A. (2007). Histopathological study on the parasitised visceral organs of some fishes of Lekki Lagon, Lagos, Nigeria. Life Science Journal, 4(3), 70-76.

Camargo, M.M.P. \& Martinez, C.B.R. (2007). Histopathology of gills, kidney and liver of a neotropical fish caged in an urban stream. Neotropical Ichthyology, 5(3), 327-336.

Grabda, J. (1991). Marine fish parasitology. Warszawa: PWN-Polish Scientific Publishers, 305 pp.

Hadiroseyani, Y., Hariyadi, P., \& Nuryati, S. (2006). Inventarisasi parasit lele dumbo Clarias $\mathrm{sp}$. di daerah Bogor. Jurnal Akuakultur Indonesia, 5(2), 167-177.

Hoffman, G.L. (1999). Parasites of American freshwater fishes. 2nd ed. New York: Cornell University Press, p. 122-129.

Hossain, M.K., Hossain, M.D., \& Rahma, M.H. (2007). Histopathology of some diseased fishes. Journal Life Earth Science, 2(2), 47-50.

Kabata, Z. (1985). Parasites and diseases of fish control in the tropics. Taylor and Francis. London and Philadelphia, $318 \mathrm{pp}$.

Khairuman \& Sudenda, D. (2009). Budidaya patin secara intensif. Jakarta: Agromedia Pustaka, $116 \mathrm{hlm}$.

Price, S.A. \& Wilson, L.M. (2006). Patologi konsep klinis proses-proses penyakit. Brahma, U.P. penterjemah: Huriawati, H. Edit. Jakarta: EGC Terjemahan dari: Pathopysiology Clinical Concepts of Disease Processes, 1183 pp.

Raškoviæ, B.S., Stankovi, M.B., Markovi, Z.Z., \& Poleksi, V.D. (2011). Histological methods in the assessment of different feed effects on liver and intestine of fish. Journal of Agricultural Sciences, 56(1), 87-100.

Roberts, R.J. (2001). Fish pathology. Edisi III. Saunders, W.B. London, Edinburgh, Philadelphia, St. Louis, Sydney, Toronto, $472 \mathrm{pp}$.

Rohde, K. (2005). Marine parasitology. Australia: CSIRO Publishing, p. 189-196.

Saputra, H.M., Marusin, N., \& Santoso, P. (2013). Struktur histologis insang dan kadar hemoglobin ikan asang (Osteochilus hasseltii C.V) di Danau Singkarak dan Maninjau, Sumatera Barat. J. Bio. UA., 2(2), 138-144.

Sayed, A.H., Mekkawy, I.A., \& Mahmoud, U.M. (2012). Histopathological alterations in some body organs of adult Clarias gariepinus (Burchell, 1822) exposed to 4-nonylphenol. In Garcia, M.D. (ed). Zoology. In Tech. Shanghai, p. 163-184. 
Snieszko, S.F. (1973). The effect of environmental stress on outbreak of infection disease of fisheries. J. Fish. Biol., 6, 197-208.

Susanto, D. (2008). Gambaran histopatologi organ insang, otot dan usus ikan mas (Cyprinus carpio). Fakultas Kedokteran Hewan. Institut Pertanian Bogor. Bogor.

Tobing, L.L. (2000). Inventarisasi parasit metazoa pada ikan gabus laut (Saurida undosquamis Richardson, 1848), ikan samgeh (Antrobucca nibe Jordan dan
Thompson, 1911) dan ikan gelang mudin (Upeneus taeniopterus Cuvier, 1829) dari tempat pelelangan ikan Pelabuhan Ratu, Jawa Barat. Skripsi. Fakultas Perikanan dan Ilmu Kelautan, Institut Pertanian Bogor. Bogor, $104 \mathrm{hlm}$.

Wakita, K., Yuasa, K., Panigoro, N., Bahnan, M., Salfira, $\&$ Astuti, I. (2007). Teknik dasar histologi dan atlas dasar-dasar histopatologi ikan. Balai Budidaya Air Tawar Jambi dan Japan International Coperation Agency. Sumatera, $77 \mathrm{hlm}$. 